\title{
Applying Cassava Stems Biochar Produced from Agronomical Waste to Enhance the Yield and Productivity of Maize in Unfertile Soil
}

\author{
Saowanee Wijitkosum ${ }^{1, *}$ and Thavivongse Sriburi ${ }^{2}$ \\ 1 Environmental Research Institute, Chulalongkorn University, Bangkok 10330, Thailand \\ 2 Pa-deng Biochar Research Center, Phetchaburi 76170, Thailand; thavivongse.s@chula.ac.th \\ * Correspondence: saowanee.w@chula.ac.th
}

Citation: Wijitkosum, S.; Sriburi, T. Applying Cassava Stems Biochar Produced from Agronomical Waste to Enhance the Yield and Productivity of Maize in Unfertile Soil. Fermentation 2021, 7, 277. https://doi.org/ $10.3390 /$ fermentation7040277

Academic Editor:

Emmanuel Atta-Obeng

Received: 14 October 2021

Accepted: 20 November 2021

Published: 25 November 2021

Publisher's Note: MDPI stays neutral with regard to jurisdictional claims in published maps and institutional affiliations.

Copyright: () 2021 by the authors. Licensee MDPI, Basel, Switzerland. This article is an open access article distributed under the terms and conditions of the Creative Commons Attribution (CC BY) license (https:// creativecommons.org/licenses/by/ $4.0 /)$.

\begin{abstract}
Many agronomical wastes are produced annually in significant amounts after cultivation, especially in agricultural countries. This study applied biochar produced from the pyrolysis of cassava stems to improve soil with low fertility for maize cultivation. The effect of soil biochar incorporation on maize yield and productivity was also investigated. Eight experimental plots, each with four replicates, were applied with cassava stem biochar (CSB) at different rates of $0.5 \mathrm{~kg} / \mathrm{m}^{2}$ (TB0.5), $2.5 \mathrm{~kg} / \mathrm{m}^{2}$ (TB2.5) and $3.0 \mathrm{~kg} / \mathrm{m}^{2}$ (TB3.0), fertilizer at $0.56 \mathrm{~kg} / \mathrm{m}^{2}$ (TM), fertilizer at $0.56 \mathrm{~kg} / \mathrm{m}^{2}$ mixed with CSB at $0.5 \mathrm{~kg} / \mathrm{m}^{2}$ (TMB0.5), $2.5 \mathrm{~kg} / \mathrm{m}^{2}$ (TMB2.5), $3.0 \mathrm{~kg} / \mathrm{m}^{2}$ (TMB3.0) and untreated soil (TC). Pyrolysis of cassava stems at $450-500{ }^{\circ} \mathrm{C}$ produced strongly alkaline CSB with $\mathrm{pH} 9.6$ and increased nutrient contents. Specific surface area and total pore volume increased, and pores were classified as mesoporous, while average pore diameter decreased. CSB had a highly stable carbon content of $58.46 \%$, with high aromaticity and polarity obtained from $\mathrm{O} / \mathrm{C}$ and $\mathrm{H} / \mathrm{C}$ ratios. Results indicated that CSB enhanced and supported maize growth by improving soil physicochemical properties to suit cultivation. Applying CSB into the soil gave higher maize yield and productivity than cultivation using fertilizer. The highest yield and nutrition contents were obtained in seed from cultivation using fertilizer mixed with biochar at $3.0 \mathrm{~kg} / \mathrm{m}^{2}$. Biochar production from cassava stems generated a useful commodity from waste material.
\end{abstract}

Keywords: biochar; cassava stems; agricultural wastes; maize yields; soil amendment; resilient agricultural

\section{Introduction}

Many agricultural areas suffer from soil degradation caused by erosion. Moreover, depletion of organic matter and changes in land use adversely impact global agricultural productivity and food security. Soil degradation results from improper agricultural management, overgrazing, and deforestation [1-4]. Agricultural areas produce wastes as biomass. Elimination of these wastes in cultivated areas by burning causes air pollution and destruction of the soil. These issues present obstacles to human development and threaten natural resources and the environment.

In 2015, the UN set 17 sustainable development goals (SDSs) [5], with three SDGs related to soil degradation. SDG 15: "Life on land" states as Target 15.3: "End desertification and restore degraded land." Combating desertification and restoration of degraded soil resources are operations to achieve this goal. An essential guideline in combating desertification and soil degradation is restoring soil resources, increasing soil productivity, preventing droughts and flooding and reducing soil erosion risk [1]. Soil restored to good condition is also effective in achieving SDG 2: "Zero hunger" as Target 2.4. Target 2.4 aims to create a sustainable food production system by appropriate farming patterns that increase agricultural productivity and production while maintaining ecosystems and strengthening adaptation to climate change. SDG 12: "Creating sustainable production 
and consumption patterns" is another crucial sustainable development goal that involves managing natural resources effectively and reducing waste generation through recycling, reuse and upcycling.

Soil resources are directly related to SDG 15 and SDG 2, with indirect relevance to SDG 12 through the contribution of soil to ecosystem services. Realizing the soil resources by restoring and caring for the soil is important to accomplish sustainable development. To achieve these three SDGs, solving the problem of degraded soil resources by applying organic amendments is a strategy to create environmental sustainability for natural resources consumption and waste disposal. Solving degraded soil and enhancing soil fertility to suit planting by agricultural waste management is a challenge for many countries, especially agricultural production bases [6]. Thailand has experienced soil degradation with unfertile soil, especially in the north-eastern and western regions of the country $[1,3]$.

Thailand has a large agricultural production base involved in field crop production, such as cassava and corn. After harvesting, the country produced 43 million tons of agricultural waste annually, including cassava stems and rhizomes, at about 3.4 million tons $[6,7]$. Typically, most cassava stems are eliminated by burning in the planting area. Burning is convenient, quick, low cost, and allows fast field preparation for subsequent cultivation but causes problems for farmers and the environment. Therefore, the upcycling of agricultural waste to valuable products, especially by producing biochar as a soil amelioration, will assist farmers in improving soil resources and also benefit the environment.

Improving the deteriorated soil resources for agriculture can increase agricultural productivity since using excessive chemical fertilizers for a long time causes a long-term impact on the environment, ecosystems, and human health. Contamination and residues in the soil and the water had been reported in farming and related areas that use chemical fertilizers, resulting in soil pollution problems and eutrophication in the surface water [1,4], especially in the tropical region where fertilizers are easily leached. Therefore, the farmers used more fertilizers to maintain nutrients in the soil to control agricultural productivity and quality. In addition to being harmful to the environment and ecosystems, these cultivation patterns also affected the socioeconomic status of farmers. Farmers in Thailand had been experiencing the high cost of agricultural production, and most costs were chemical fertilizers and pesticides. They spent about USD 965/ha or about $40 \%$ of the average total cost for maize cultivation [8], and the fertilizer cost depended on the soil condition, types of plants, and pattern of cultivation.

Biochar is an organic carbon-rich material produced from a wide variety of lignocellulosic biomass such as agricultural wastes (rice husk, crop straws, seeds, peels, nutshells, barks, corncob, bagasse, etc.) and wood chips under pyrolysis [6,8-11]. The primary constituents of lignocellulosic biomass comprise cellulose, hemicellulose, and lignin [6,12-14], which differ in components depending on plant type, plant growth conditions, part of the plant, and age at harvesting [15-17]. These constituents affect the final product when passing the pyrolysis process $[8,14,16,18-20]$. Therefore, the wide variety of feedstock provides different biochar properties [11,13,15,20-23]. In addition to raw materials for biochar production, pyrolysis conditions also affect the properties of biochar and the final behaviour of the resulting biochar in the soil [9,13,24-29].

Biochar shows high potential for varied uses in agriculture and environmental purposes [6,22,30-34]. Using biochar in agriculture is intended to achieve two goals: improving and enhancing soil properties to benefit cultivation [35-38] as well as increasing agricultural productivity [22,39-41]. The soil improved the physicochemical and biological properties by the mechanism of biochar in the soil [24,28,41-44]. Biochar can also be used to treat soil contaminated with heavy metals and reduce toxin contamination in the environment [45-47], revitalize salt-affected soil, [48], enhance carbon storage in the soil $[42,49,50]$ and carbon sequestration in plant biomass to tackle long-term climate change $[24,31,49,51,52]$ for soil resource management, and facilitate the development of sustainable land use [53-56]. Furthermore, several studies point out that biochar can pro- 
mote sustainable agriculture by improving the soil ecosystem, increasing productivity, and reducing fertilizer [11,53,56-61], which is a good result for farmers and the environment.

Although the previous studies had shown that biochar effectively increased productivity and improved soil properties [25,27,56,62,63], using biochar for agriculture should also be continuously studied due to the difference of the cultivation environment, different cultivation patterns and to solve the area's specific conditions and problems. Research on biochar produced from local feedstocks is an important and good choice for farmers [6], and the appropriate ratio of biochar used with soil resources is necessary for farmers to use widely. However, good quality biochar often requires a complex production process with a robust and effective furnace to make biochar production at high prices. Farmers cannot produce biochar by themselves; thus, it is an obstacle for poor farmers.

This research focused on agricultural self-sufficiency patterns and reduced chemical fertilizer usage, positively impacting the ecosystem and farmers' quality of life. Therefore, biochar was produced from local feedstocks using a low-cost furnace with appropriate technology suitable for rural farmers. This research aimed to produce biochar from cassava stems as agronomical wastes in Thailand to improve the soil properties and enhance the productivity of maize. Moreover, organic fertilizer was produced from local agricultural residues. The results show that only the first planting cycle can lead to the expansion of the use of biochar by local farmers to improve soil properties and increase agricultural productivity. Moreover, the results created an understanding for farmers to change the cultivated using biochar with organic fertilizer. The role model and cooperation between community leaders and government agencies were vital in conveying the knowledge of biochar for agriculture.

\section{Materials and Methods}

\subsection{Experimental Study Area}

The application of cassava stem biochar (CSB) to increase maize productivity in agricultural areas with poor soil fertility was conducted at Pa Deng Sub-district, Kaeng Krachan District, Phetchaburi Province, Thailand. The experimental area was at the PadengBiochar Research Center (Pd-BRC), an experimental and expanding area of biochar research of the Huay Sai Royal Development Study Center.

The Pa Deng area covers an area of approximately $417.80 \mathrm{~km}^{2}$. Geographically, it is located between the latitudes $1,409,557.500856 \mathrm{~m}$ to $1,386,435.510378 \mathrm{~m}$, and longitude $536,737.802155 \mathrm{~m}$ to $568,817.211385 \mathrm{~m}$ at an altitude of $140 \mathrm{~m}$ above mean sea level. About $86.35 \%$ of the area is an evergreen forest in Kaeng Krachan National Park-a world heritage site. Therefore, there is a flat plain area, only about $15 \%$ of the total area for human settlement and activities. The soil resource in the area is sandy loam which is slightly alkaline to extremely acidic. The soil has meagre fertility with an organic matter (OM) of 0.04-0.16 and high permeability [64]. The area of about $3.77 \mathrm{~km}^{2}$ is used for the settlement of ten communities with approximately 4500 people. Approximately $12.36 \%$ of the total area of Pa Deng is utilized to cultivate agronomy and horticulture. Due to the limited agricultural area, as a result, intensive farming in the area and the heavy use of agrochemicals degrade the soil and have high agricultural costs.

\subsection{Research Design and Experimental Plots}

Eight planting areas were laid out, each with four replications giving thirty-two experimental plots. Each plot was $3 \mathrm{~m}$ wide and $5 \mathrm{~m}$ long. Eight plants were spaced in a row $75 \mathrm{~cm}$ apart with $25 \mathrm{~cm}$ between each plant. Each experimental treatment had four replicates containing eighty maize plants. The eight experimental treatments were classified into four groups as follows: Group 1 was the experimental set with only biochar applied at rates of $0.5 \mathrm{~kg} / \mathrm{m}^{2}$ (TB0.5), $2.5 \mathrm{~kg} / \mathrm{m}^{2}$ (TB2.5) and $3.0 \mathrm{~kg} / \mathrm{m}^{2}$ (TB3.0). Group 2 treatments applied fertilizers (compost) at $0.56 \mathrm{~kg} / \mathrm{m}^{2}(\mathrm{TM})$ as a general cultivation pattern for farmers in the area. Group 3 consisted of experimental control treatments of untreated soil (TC), while Group 4 treatments applied fertilizers at the same rates of $0.56 \mathrm{~kg} / \mathrm{m}^{2}$ and 
added biochar at different ratios at $0.5 \mathrm{~kg} / \mathrm{m}^{2}$ (TMB0.5), $2.5 \mathrm{~kg} / \mathrm{m}^{2}$ (TMB2.5) and $3.0 \mathrm{~kg} / \mathrm{m}^{2}$ (TMB3.0). A completely randomized design was applied to study the effect of biochar on maize growth and productivity.

Maize (Zea mays L.) as a single-cross hybrid CP 888 variety (flint corn) was selected for this research. This variety is drought tolerant with strong stems, grows well in upland areas with low to medium precipitation [65] and is suitable for cultivation in the Pa Deng area. The maize was planted in May with harvesting in August. The experimental period was without rain with full sun, and the plants were watered using sprinklers.

The fertilizer used in this experiment was made from the compost of soybean residues (stems and leaves) for 45 days. The stems and leaves of soybean are wastes after harvesting. The fertilizer was analysed in heaps to determine its chemical properties. The soybean compost was moderately alkaline with $\mathrm{pH}$ of 8.3 and electrical conductivity (EC) of $3.50 \mathrm{dS} / \mathrm{m}$. The fertilizer had a high OM of $23.43 \%$. It contained a high amount of macronutrients with total nitrogen (total $\mathrm{N}$ ) content of $1.70 \mathrm{wt} . \%$, phosphorous (total $\mathrm{P}_{2} \mathrm{O}_{5}$ ) $0.87 \mathrm{wt} . \%$ and potassium (total $\mathrm{K}_{2} \mathrm{O}$ ) $3.54 \mathrm{wt} . \%$. The total organic carbon (total OC) of soybean compost was $23.42 \mathrm{wt} . \%$, with a ratio of carbon and nitrogen $(\mathrm{C} / \mathrm{N})$ of 13.75 . Following the DOA Notice on the Standard of Organic Fertilizers [66], the analysis results indicated that soybean compost had chemical properties that meet the standard.

\subsection{Feedstock, Biochar Production and Their Characteristic Analyses}

The cassava stems, which farmers cut and leave in cultivated areas, were feedstock for biochar production. The cassava stems were cut to $15-20 \mathrm{~cm}$ in length and were exposed to the sun for two days. The Controlled Temperature Biochar Retort for Slow Pyrolysis Process (CTBRSPP) (patented number 50528) was built to produce good quality biochar under pyrolysis conditions at $450-500{ }^{\circ} \mathrm{C}$ with an uncomplicated process. The temperature and pyrolysis conditions were controlled by restricting the air-in-out of the furnace by the number and size of drilled holes. The patented furnace showed the highest biochar yields while using the least amount of fuel; with the drill, the outer furnace has eight holes and inner biochar retort with four holes, all of which had a diameter of $2.5 \mathrm{~cm}$ [11]. In addition, the ratio of biomass with fuel that was the most effective condition of the pyrolysis was 1.0:0.6 [6,31]. The use of agricultural wastes as a raw material for biochar production and fuel from local wood chips resulted in most biochar production costs for the furnace. The cost of the patented furnace used in this study was approximately USD 50 [11,31], which could be used to produce biochar 45-60 times.

According to the Standardized Product Definition and Product Testing Guidelines for Biochar used in Soil [67], biochar is randomly sampled from every biochar production process for morphology and physicochemical properties analysis $[6,11]$. The morphology and physicochemical properties of cassava stems were analysed. The scanning electron microscope (SEM) on the JEOL JEM-5410LV SEM machine was used to conduct biochar and feedstock surface morphology and surface characteristics analysis [68]. The specific surface areas were analysed using Brunauer-Emmett-Teller (BET) method [69], and the total pore volume and average pore diameter were analysed by Barrett-Joyner-Halenda (BJH) method [31,70,71].

The analysis of the element composition of biomass and biochar consisted of $\mathrm{C}, \mathrm{H}, \mathrm{N}$, and oxygen $(\mathrm{O})$ contents. The elemental contents of $\mathrm{C}, \mathrm{H}$, and $\mathrm{N}$ were measured using the Elemental Analyzer, Leo TruSpec CHN model [72]. Total OC content was measured using the combustion-infrared method with a TOC analyzer (Shimadzu TOC Tcvh) [73]. The $\mathrm{H} / \mathrm{C}$ and $\mathrm{C} / \mathrm{N}$ molar ratios were also calculated [31,72]. The molar $\mathrm{H} / \mathrm{C}, \mathrm{O} / \mathrm{C}$, and $\mathrm{C} / \mathrm{H}$ ratios were used to determine the degree of aromaticity and biochar maturation [74-76]. It also indicated the pyrolysis level and the degree of biochar oxidative adjustment in the soil $[23,35,77-79]$.

The $\mathrm{pH}$ and EC were measured in $1 \mathrm{~m} \mathrm{KCL}$ solution after shaking the sample for $1 \mathrm{~h}$ with a $\mathrm{pH}$ measured at 1:2 $(v / v)$, while EC was measured at 1:5 $(v / v)$ ratio [31,48]. The $\mathrm{CEC}$ was analysed using ammonium acetate extraction (1.0 $\left.\mathrm{N} \mathrm{NH}_{4} \mathrm{OAc} \mathrm{pH} 7.0\right)$ [69]. The 
CEC measured the ion exchange potential at the biochar surface related to the biochar's age $[24,73,80]$. The total $\mathrm{N}$ was analysed using the Kjeldahl method and distillation apparatus. The spectrophotometric molybdovanadophosphate method was used to analyse the available phosphorous in the form of $\mathrm{P}_{2} \mathrm{O}_{5}$ content at a wavelength of $420 \mathrm{~nm}$. Analysis of exchangeable potassium as $\mathrm{K}_{2} \mathrm{O}$ and $\mathrm{Mg}$ by extraction with $1 \mathrm{M} \mathrm{NH}_{4} \mathrm{OAc}$ at $\mathrm{pH} 7$ was measured with atomic absorption spectrophotometer (AAS) [81,82]. Moreover, the Walkley and Black method were used for OM analysis [83].

\subsection{Soil Sampling and Soil Character Analysis}

Soil sampling was randomly selected from the soil at a depth of $15-20 \mathrm{~cm}$ from the topsoil by collecting soil samples distributed throughout each plot. The soil was sampled to analyse the change of physicochemical properties, both before and after maize cultivation. The vital soil physiochemical properties included $\mathrm{pH}, \mathrm{CEC}, \mathrm{OM}$, total N, exch. K analysed similarly to biochar analysis. Available phosphorous (avail. P) in the soil was in the form of $\mathrm{H}_{2} \mathrm{PO}^{4-}$ and $\mathrm{HPO}^{4-}$. The avail. $\mathrm{P}$ was determined using the Bray II method with $0.1 \mathrm{~N} \mathrm{HCl}$ and $\mathrm{NH}_{4} \mathrm{~F}$ [83] by spectrophotometer. Soil texture analysis using hydrometer method by defining the particle size division were as follows: sand had an effective diameter of 0.05-2.00 mm, silt had an effective diameter $0.002-0.05 \mathrm{~mm}$, and clay had an effective diameter of smaller than $0.002 \mathrm{~mm}$ [84].

\subsection{Analysis of Maize Production and Maize Seed Nutritional Value}

At the end of the growing season, maize was harvested and analysed for quantity and quality yields. Maize yields were measured by the number of ears of maize, the weight of fresh and dry kernels, and seed biomass. Dry maize kernels were weighed after baking at $105{ }^{\circ} \mathrm{C}$ for $48 \mathrm{~h}$. The biomass of seeds was calculated as (fresh weight $\left.{ }^{*} 100\right) /(\%$ moisture + 100) [85].

The Association of Official Analytical Chemists [86] evaluates maize yield quality and the nutritional value in maize kernels by proximate analysis method. The nutritional value in maize kernels was measured as \%protein, \%carbohydrate, and \%fat. The Kjeldahl technique was used to analyse the protein content, with fat content analysed using ether extract. Moisture content was evaluated by drying, using the vacuo method at $103-105{ }^{\circ} \mathrm{C}$ for $48 \mathrm{~h}$, while carbohydrate content was calculated by $100 \%$-DX\%moisture $+\%$ fat (lipid) + $\%$ protein $+\%$ ash). Ash content was determined by sintering at $500-550{ }^{\circ} \mathrm{C}$ in an electric muffle furnace for $2-4 \mathrm{~h}$ [86].

\subsection{Data Analysis}

Data on biochar and soil properties, maize yield, productivity, and seed nutritional value from different experimental treatments, expressed as the mean \pm standard deviation (SD), were derived from four replicates. Analysis of variance of maize yield, productivity, and nutritional value of kernels obtained from each experimental plot used multiple comparisons technique with Fisher's least significant difference (LSD). Tukey's multiple comparison test was used to analyse the variance of soil properties after maize cultivation. Analysis of differences in the statistical significance of every data set was at $95 \%$ confidence level. The Statistical Package of the Social Science (SPSS) software was used to process the statistical data analysis.

\section{Results}

\subsection{Characteristics and Properties of Cassava Stems and Cassava Stem Biochar}

Analysis of the physical structure of feedstock showed that the cassava stems had a surface area of $2.514 \mathrm{~m}^{2} / \mathrm{g}$, a total pore volume of $0.0058 \mathrm{~cm}^{3} / \mathrm{g}$, and an average pore diameter of $83.344 \AA$ (8.334 nm). After cassava stems were pyrolyzed, analysis results revealed that the CSB showed an increased specific surface area of $200.459 \mathrm{~m}^{2} / \mathrm{g}$, with a total pore volume of $0.122 \mathrm{~cm}^{3} / \mathrm{g}$. The average pore diameter decreased to $24.358 \AA$ $(2.436 \mathrm{~nm})$, classified as mesoporous. The cassava stems had a total C of $41.55 \mathrm{wt} \%$, total 
H 6.04 wt.\%, total N 1.36 wt.\%, and total O 51.14 wt.\%. The C/N molar was 39.90, with $\mathrm{H} / \mathrm{C} 1.74$ and $\mathrm{O} / \mathrm{C} 0.92$.

Chemical composition analyses revealed that CSB contained a total C of $58.46 \%$, equal to total OC, with total $\mathrm{H}$ content $2.25 \%$, total $\mathrm{N} 1.28 \%$, and total $\mathrm{O} 38.01 \%$. The H/C and $\mathrm{O} / \mathrm{C}$ ratios at 0.39 and 0.65 , respectively, specified the stability of the biochar in the environment. Carbon compounds in CSB were highly stable, with low $\mathrm{H}$ and $\mathrm{N}$ content and low $\mathrm{O} / \mathrm{C}$ and $\mathrm{H} / \mathrm{C}$ molar ratios. The $\mathrm{C} / \mathrm{N}$ ratio of $\mathrm{CSB}$ was 45.78 , which was higher than feedstocks. Analysis results of the physical structure and chemical composition of cassava stems and CSB are shown in Table 1.

Table 1. Physical properties of cassava stems and cassava stem biochar.

\begin{tabular}{cccc}
\hline Parameters & Units & Cassava Stems & Cassava Stems Biochar \\
\hline Physical Properties & & & \\
\hline $\begin{array}{c}\text { Specific surface area } \\
\text { Total pore volume }\end{array}$ & $\mathrm{m}^{2} / \mathrm{g}$ & $2.514 \pm 0.030$ & $200.459 \pm 0.520$ \\
Average pore diameter & $\mathrm{cm}^{3} / \mathrm{g}$ & $0.0058 \pm 0.001$ & $0.122 \pm 0.004$ \\
\hline Compositions & $\AA$ & $83.344 \pm 1.790$ & $24.358 \pm 1.590$ \\
\hline C & & & $58.46 \pm 0.104$ \\
OC & $w t . \%$ & $41.55 \pm 0.920$ & $58.46 \pm 0.006$ \\
H & $w t . \%$ & $6.04 \pm 0.130$ & $2.25 \pm 0.107$ \\
O & $w t . \%$ & $1.36 \pm 0.006$ & $38.01 \pm 0.031$ \\
C/N Ratio & $w t . \%$ & $51.14 \pm 1.181$ & $45.78 \pm 1.133$ \\
H/C Ratio & $w t . \%$ & $39.90 \pm 3.530$ & $0.39 \pm 0.001$ \\
O/C Ratio & $w t / w t$ & $1.74 \pm 0.062$ & $0.65 \pm 0.003$ \\
\hline
\end{tabular}

The cassava stems were slightly acid, with a $\mathrm{pH}$ of 6.58 and EC of $1.97 \mathrm{dS} / \mathrm{m}$ and CEC of $25.72 \mathrm{cmol} / \mathrm{kg}$. The cassava stems contained $88.55 \% \mathrm{OM}$, with essential nutrients as total $\mathrm{N} 0.91 \%$, total $\mathrm{P}_{2} \mathrm{O}_{5} 0.34 \%$, total $\mathrm{K}_{2} \mathrm{O} 0.60 \%$ and total $\mathrm{Mg} 0.38 \%$. After the cassava stems underwent the pyrolysis process, the CSB was strongly alkaline ( $\mathrm{pH} \mathrm{9.6).} \mathrm{The} \mathrm{EC} \mathrm{value}$ $(1.35 \mathrm{dS} / \mathrm{m})$ and CEC decreased $(11.0 \mathrm{cmol} / \mathrm{kg})$. The CSB contained high levels of OM at $25.90 \%$ and high macronutrient, with total $\mathrm{N} 0.98 \%$, total $\mathrm{P}_{2} \mathrm{O}_{5} 0.82 \%$, total $\mathrm{K}_{2} \mathrm{O} 1.68 \%$, and total $\mathrm{Mg} 0.97 \%$. Table 2 shows the analysis results of cassava stems and CSB properties.

Table 2. Chemical properties of cassava stems and cassava stem biochar.

\begin{tabular}{cccc}
\hline Parameters & Units & Cassava Stems & Cassava Stems Biochar \\
\hline Chemical Properties & & & \\
\hline $\mathrm{pH}$ & - & $6.58 \pm 0.096$ & $9.60 \pm 0.180$ \\
$\mathrm{EC}$ & $\mathrm{dS} / \mathrm{m}$ & $1.97 \pm 0.018$ & $1.35 \pm 0.024$ \\
$\mathrm{CEC}$ & $\mathrm{cmol} / \mathrm{kg}$ & $25.72 \pm 0.768$ & $11.00 \pm 0.252$ \\
$\mathrm{OM}$ & $\%$ & $88.55 \pm 0.450$ & $25.89 \pm 0.623$ \\
\hline Nutrients & & \\
Total $\mathrm{N}$ & $\%$ & $0.91 \pm 0.030$ & $0.98 \pm 0.049$ \\
Total $\mathrm{P}_{2} \mathrm{O}_{5}$ & $\%$ & $0.34 \pm 0.026$ & $0.82 \pm 0.025$ \\
Total $\mathrm{K}_{2} \mathrm{O}$ & $\%$ & $0.60 \pm 0.017$ & $1.68 \pm 0.020$ \\
Total $\mathrm{Mg}$ & $\%$ & $0.38 \pm 0.028$ & $0.97 \pm 0.015$ \\
\hline
\end{tabular}

\subsection{Maize Yield and Productivity}

After harvesting, the TMB2.5 plots produced the highest maize yield with 143 pods, while TMB3.0 plots gave 142 pods. The lowest ears of maize were obtained from TC at 118 pods, which recorded pod numbers significantly lower than the other plots, except for TM (128 pods), TB0.5 (131 pods), and TMB0.5 (125 pods). The experimental plots with only CSB at every rate (TB0.5, TB2.5, TB3.0) provided more maize ears than TM and TC (Figure 1). 


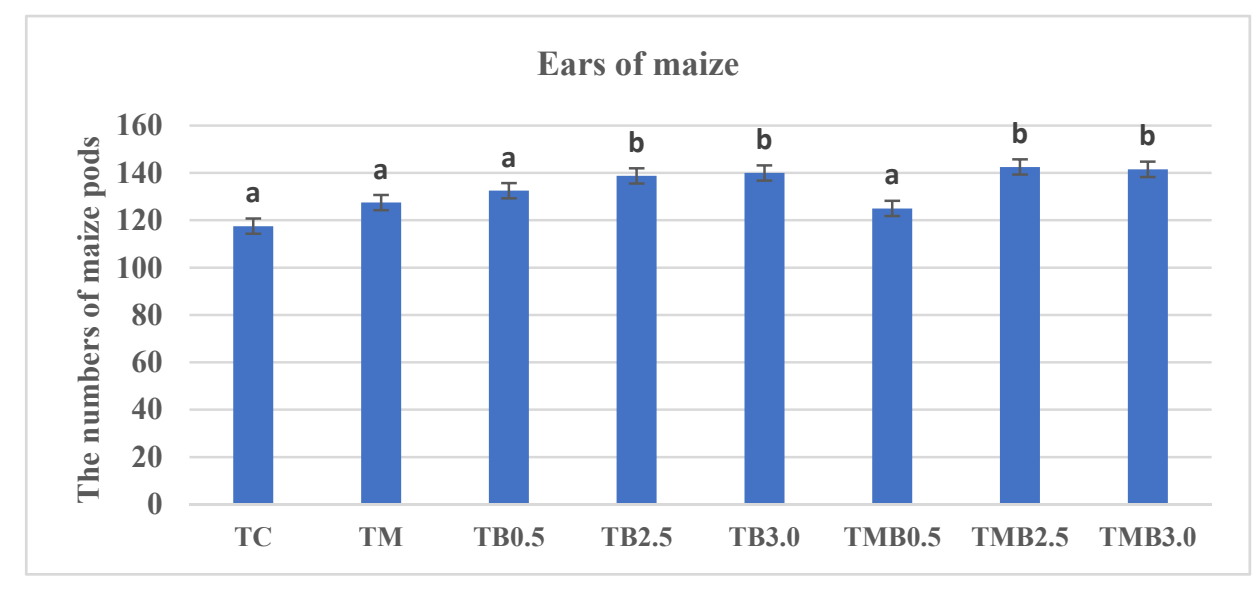

Figure 1. The number of ears of maize from different experimental plots. Remark: data shown as the mean \pm SE with harmonic mean sample size $=4.000$. The different letters represent a statistically significant difference in the data at $p<0.05$.

The moisture content of maize seeds obtained from every experimental plot was $12.988-13.581 \%$, which was in accordance with class 1 as the best grade of maize standards (13-14\%) of the Department of Agriculture, Thailand. The biomass of seeds had the highest value in TMB3.0 (60.280 ton/ha) and the lowest in TC (50.098 ton/ha). Biomass of seeds ( 50.557 ton/ha) obtained from the TM plots was equal to the TB2.5 plots, with no significant difference from TB0.5 (50.556 ton/ha). Maize cultivated using CSB at the highest rate (TB3.0) yielded maize seed with biomass (50.923 ton/ha) higher than cultivating with fertilizer mixed with CSB at the lowest rate (50.680 ton/ha, TMB0.5). However, the biomass of seeds in every experimental plot was not significantly different. Maize yield and productivity from different experimental plots are shown in Table 3.

Table 3. The maize yield and productivity from different experimental plots.

\begin{tabular}{ccccc}
\hline Experimental Plots & \% Moisture & $\begin{array}{c}\text { Biomass of Seeds } \\
\text { (ton/ha) }\end{array}$ & $\begin{array}{c}\text { Dry Weight of Seeds } \\
\text { (ton/ha) }\end{array}$ & $\begin{array}{c}\text { Fresh Weight of Seeds } \\
\text { (ton/ha) }\end{array}$ \\
\hline TC & $12.988 \pm 1.0709$ & $50.098 \pm 0.9017$ & $60.004 \pm 0.9668$ & $70.103 \pm 1.0354$ \\
TM & $13.076 \pm 0.5535$ & $50.557 \pm 1.3002$ & $60.285 \pm 1.4765$ & $70.233 \pm 1.7086$ \\
TB0.5 & $13.535 \pm 0.9423$ & $50.556 \pm 0.3946$ & $60.340 \pm 0.4254$ & $70.332 \pm 0.4664$ \\
TB2.5 & $13.125 \pm 0.9625$ & $50.577 \pm 0.7740$ & $60.521 \pm 0.8263$ & $70.500 \pm 0.8796$ \\
TB3.0 & $13.489 \pm 0.6964$ & $50.923 \pm 1.2369$ & $60.718 \pm 1.3894$ & $70.762 \pm 1.5864$ \\
TMB0.5 & $13.263 \pm 0.6331$ & $50.680 \pm 1.6274$ & $60.428 \pm 1.8286$ & $70.403 \pm 2.0865$ \\
TMB2.5 & $13.427 \pm 1.1413$ & $60.134 \pm 1.2577$ & $60.951 \pm 1.3835$ & $80.022 \pm 1.5411$ \\
TMB3.0 & $13.581 \pm 0.8166$ & $60.280 \pm 0.8513$ & $70.128 \pm 0.9197$ & $80.242 \pm 0.9929$ \\
\hline
\end{tabular}

Remark: data shown as the mean \pm SE with harmonic mean sample size $=4.000$.

Dry weight and fresh weight of seeds had the highest value in TMB3.0 (70.128 ton/ha and 80.242 ton/ha) and the lowest value in the TC (60.004 ton/ha and 70.103 ton/ha). Maize obtained from experimental plots that applied CSB at all rates (TB0.5, TB2.5, TB3.0) had seeds with dry weight and fresh weight higher than the maize obtained from cultivation applied with fertilizer (TM). Maize grown in experimental plots mixed with CSB at 2.5 (TB2.5) and $3.0 \mathrm{~kg} / \mathrm{m}^{2}$ (TB3.0) gave higher weights of dry seeds and fresh seeds than maize grown by applying fertilizer mixed with CSB at the lowest rate (TMB0.5).

\subsection{Protein, Carbohydrate, and Fat in Maize Seeds}

As well as maize production, the quality of seeds was also essential to increase the selling price. Seed quality was evaluated by the amounts of protein, carbohydrate, and fat in the seeds. The results of nutritional components by proximate analysis are shown in Table 4. 
Table 4. Percentage of protein, carbohydrate, and fat content in maize seeds in different experimental plots.

\begin{tabular}{cccc}
\hline Experimental Plots & \% Protein & \% Carbohydrate & \% Fat \\
\hline TC & $7.1025 \pm 0.4031$ & $70.2400 \pm 0.4493$ & $3.7700 \pm 0.3665$ \\
TM & $7.2650 \pm 0.4823$ & $71.5025 \pm 1.8000$ & $3.9450 \pm 0.4015$ \\
TB0.5 & $7.1825 \pm 0.8778$ & $70.7950 \pm 1.9165$ & $3.7050 \pm 0.1877$ \\
TB2.5 & $7.2275 \pm 1.0192$ & $71.4250 \pm 0.7230$ & $4.0900 \pm 0.2947$ \\
TB3.0 & $7.5700 \pm 0.3976$ & $72.4000 \pm 0.5303$ & $4.1525 \pm 0.3423$ \\
TMB0.5 & $7.4000 \pm 0.3529$ & $71.3250 \pm 1.0648$ & $4.1453 \pm 0.2309$ \\
TMB2.5 & $7.5375 \pm 0.5088$ & $72.0850 \pm 0.5239$ & $4.1825 \pm 0.3040$ \\
TMB3.0 & $7.6500 \pm 0.7297$ & $72.6250 \pm 0.3835$ & $4.3025 \pm 0.3305$ \\
\hline
\end{tabular}

Maize seeds grown in the TMB3.0 plots had the highest amounts of protein $(7.650 \%)$, carbohydrate $(72.625 \%)$, and fat $(4.303 \%)$ contents. The TC experimental plots provided maize seeds with the lowest protein $(7.103 \%)$, carbohydrates $(70.240 \%)$, and fat $(3.770 \%)$. In contrast, TB3.0 experimental plots that applied CSB at the highest rate gave maize seeds more protein, carbohydrates, and fat contents than seeds grown in plots using fertilizer (TM) and untreated soil (TC). Amounts of protein, carbohydrates and fat in maize seeds from each experimental plot were not significantly different; however, results indicated that the rate of CSB mixed with soil affected the quality of maize seeds. Mixing CSB into the soil at the highest rate resulted in more significant protein, carbohydrates, and fat.

\subsection{Changing in Soil Properties after Maize Cultivation}

The soil in the experiment was analysed as a sandy clay loam with neutral $\mathrm{pH}$ of 6.95, low CEC of $7.12 \mathrm{cmol} / \mathrm{kg}$ and EC of $0.08 \mathrm{dS} / \mathrm{m}$. Soil fertility was low with $1.12 \% \mathrm{OM}$ and $0.09 \%$ total N. The exch. K $(215.75 \mathrm{mg} / \mathrm{kg})$ in soil was high, with avail. P $(21.80 \mathrm{mg} / \mathrm{kg})$ and exch. $\mathrm{Mg}(125.75 \mathrm{mg} / \mathrm{kg})$ at moderate levels.

After cultivation, analysis results (Table 5) indicated that the soil was neutral to slightly alkaline ( $\mathrm{pH}$ of 7.30-7.65). Adding fertilizers mixed with biochar at $2.5 \mathrm{~kg} / \mathrm{m}^{2}$ resulted in the highest soil $\mathrm{pH}$ value. No significant difference in the soil $\mathrm{pH}$ change (7.33) was recorded between using biochar at the lowest rate (TB0.5) and applying fertilizer alone (TM). After planting in all experimental plots, the soil exhibited higher CEC $(9.95-15.05 \mathrm{cmol} / \mathrm{kg})$ than the pre-planting soil $(7.12 \mathrm{cmol} / \mathrm{kg})$. The TMB3.0 plots had the highest CEC, while TC plots had the lowest. Applying fertilizer mixed with biochar at $3.0 \mathrm{~kg} / \mathrm{m}^{2}$ and $2.5 \mathrm{~kg} / \mathrm{m}^{2}$ improved soil CEC from low to moderate. The soil $\mathrm{pH}$ was not significantly different in each experimental plot, while CEC in TMB3.0, TMB2.5, and TM plots differed significantly from the other experimental plots.

Table 5. The characteristic of soil in different experimental plots after maize cultivation.

\begin{tabular}{cccc}
\hline \multirow{3}{*}{ Plots } & \multicolumn{3}{c}{ Soil Parameters } \\
\cline { 2 - 4 } & $\mathbf{p H}$ & CEC (cmol/kg) & OM (\%) \\
\hline TC & $7.30 \pm 0.28$ & $9.95 \pm 2.97^{\mathrm{a}}$ & $1.05 \pm 0.04^{\mathrm{a}}$ \\
TM & $7.33 \pm 0.28$ & $11.75 \pm 5.66^{\mathrm{b}}$ & $1.10 \pm 0.14^{\mathrm{a}}$ \\
TB0.5 & $7.33 \pm 0.40$ & $10.85 \pm 5.85^{\mathrm{b}}$ & $1.14 \pm 0.13^{\mathrm{a}}$ \\
TB2.5 & $7.55 \pm 0.26$ & $10.45 \pm 4.61^{\mathrm{a}}$ & $1.20 \pm 0.21^{\mathrm{a}}$ \\
TB3.0 & $7.55 \pm 0.23$ & $10.75 \pm 7.24^{\mathrm{b}}$ & $1.40 \pm 0.14^{\mathrm{b}}$ \\
TMB0.5 & $7.35 \pm 0.37$ & $10.60 \pm 5.18^{\mathrm{a}}$ & $1.08 \pm 0.22^{\mathrm{a}}$ \\
TMB2.5 & $7.65 \pm 0.10$ & $12.35 \pm 3.30^{\mathrm{b}}$ & $1.30 \pm 0.12^{\mathrm{ab}}$ \\
TMB3.0 & $7.53 \pm 0.05$ & $15.05 \pm 5.57^{\mathrm{b}}$ & $1.39 \pm 0.06^{\mathrm{b}}$ \\
\hline
\end{tabular}

Remark: Data shown as the mean \pm SE with harmonic mean sample size $=4.000$. The difference letters represent a statistically significant difference in the data at $p<0.05$.

The OM content of the soil at $1.05-1.40 \%$ indicated low fertility. The amount of OM decreased in the three experimental plots; TM $(1.10 \%)$, TMB0.5 (1.08\%), and TC (1.05\%). 
The OM in post-cultivated soil had the highest value in the plots using biochar at the high rate (TB3.0, 1.40\%) but was not significantly different from the plots that applied fertilizer mixed with biochar at a high rate (TMB3.0, 1.39\%). Other experimental plots had no significantly different $\mathrm{OM}$ soil values. The results indicated that using biochar alone at every rate increased $\mathrm{OM}$ content in the soil more than adding fertilizing alone.

Soil nutrient contents changed after cultivation (Figure 2). The soil had a total N value of $0.070-0.106 \%$. The TC plots had the lowest amount of total $\mathrm{N}$ in the soil, with TMB3.0 plots recording the highest total N. The TMB3.0 (0.106\%) and TB3.0 $(0.095 \%)$ plots showed increased total $\mathrm{N}$ in the soil compared to before cultivation $(0.09 \%)$ and significantly different from TC, TM, TB0.5, TMB0.5. The TMB2.5 plots showed no change of total $\mathrm{N}$ in the soil, while the other experimental plots gave decreased total $\mathrm{N}$. The amount of avail. $\mathrm{P}$ in the soil increased in all experimental plots with the highest increase in the TMB3.0 plot $(63.50 \mathrm{mg} / \mathrm{kg})$, while TC plots recorded the lowest $(24.25 \mathrm{mg} / \mathrm{kg})$. The TM $(28.0 \mathrm{mg} / \mathrm{kg})$, TB0.5 $(27.50 \mathrm{mg} / \mathrm{kg})$ and TMB0.5 $(28.25 \mathrm{mg} / \mathrm{kg})$ plots had avail. P in the soil at similar values.
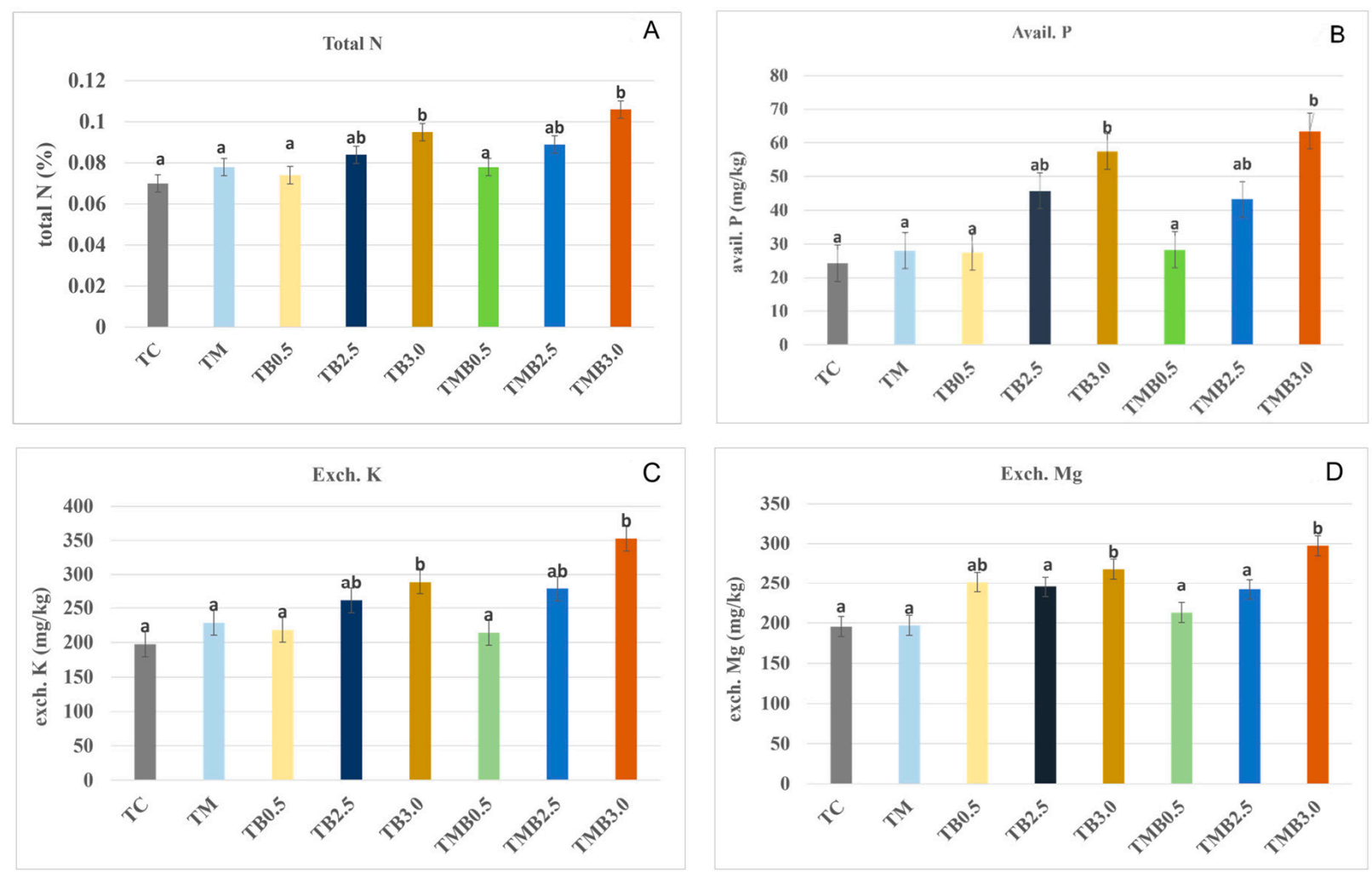

Figure 2. The total nitrogen (A), available phosphorous (B), exchangeable potassium (C), and exchangeable magnesium (D) in the soil in different experimental plots after maize cultivation. Remark: Data shown as the mean $\pm \mathrm{SE}$ with harmonic mean sample size $=4.000$. The different letters represent a statistically significant difference in the data at $p<0.05$.

The treated soil in all experimental plots showed increased exch. $\mathrm{K}(352.50-228.50 \mathrm{mg} / \mathrm{kg})$, except for TMB0.5 plot $(214.00 \mathrm{mg} / \mathrm{kg})$ that slightly reduced. The exch. $\mathrm{K}$ in soil decreased in TC plots after cultivation. The TMB3.0 plots $(352.50 \mathrm{mg} / \mathrm{kg})$ had a high level of exch. K in the soil at 1.54 times the TM plots $(228.50 \mathrm{mg} / \mathrm{kg})$ and 1.78 times TC plots $(197.50 \mathrm{mg} / \mathrm{kg})$. After cultivation, CSB mixed at the highest rate and mixing fertilizer with the highest rate of CSB gave total $\mathrm{N}$, avail. $\mathrm{P}$, and exch. $\mathrm{K}$ that were not significantly different. Both experimental plots significantly differed from the control plots (TC), the treated plots with fertilizer (TM), the treated plots with CSB at the lowest rate (TB0.5), and the plots of mixed fertilizer with CSB at the lowest rate (TMB0.5).

After cultivation, soil in all experimental plots $(195.50-297.50 \mathrm{mg} / \mathrm{kg})$ increased in exch. Mg compared with before cultivation $(125.75 \mathrm{mg} / \mathrm{kg})$. The exch. Mg content was 
lowest in TC and highest in TMB3.0. The TM $(197.00 \mathrm{mg} / \mathrm{kg})$ and TC $(195.50 \mathrm{mg} / \mathrm{kg})$ plots had exch. $\mathrm{Mg}$ in the soil with similar values. The soil in the TMB3.0 and TB3.0 $(268.00 \mathrm{mg} / \mathrm{kg}$ ) plots had similar exch. Mg contents, while the amount of exch. $\mathrm{Mg}$ in both plots significantly differed from the other plots. The results indicated that soil treated by mixing CSB at all rates had a higher amount of exch. $\mathrm{Mg}$ than soil treated with fertilizer (TM). Moreover, the exch. Mg in these plots was higher than in soil treated with fertilizer mixed with CSB at the rate of 0.5 (TB0.5) and 2.5 (TB2.5) kg/m².

The results indicated that incorporating CSB at $3.0 \mathrm{~kg} / \mathrm{km}{ }^{2}$ and CSB at $3.0 \mathrm{~kg} / \mathrm{km}$ mixed with fertilizer in sandy clay loam soil for maize cultivation could increase the total $\mathrm{N}$, avail. $\mathrm{P}$, exch. $\mathrm{K}$, and exch. $\mathrm{Mg}$ for the after cultivated soil compared to untreated soil and treated soil with fertilizer. Meanwhile, the soil chemical properties as soil $\mathrm{pH}, \mathrm{CEC}$ and OM were improved, showing no statistically significant differences.

\section{Discussion}

\subsection{The Effect of Pyrolysis and Feedstock on Biochar Properties}

The CSB was pyrolyzed using the CTBRSPP retort in the temperature range of $450-500{ }^{\circ} \mathrm{C}$. The results indicated that pyrolysis directly affects the properties of biochar, as shown from changes in physical and chemical properties of cassava stems and CSB. Pyrolysis lignocellulosic biomass made its structure and composition change at different pyrolysis temperatures $[9,13,16,20,30]$. The lignocellulosic constituents were carbonized and decomposed in different temperatures. Due to their structure, the hemicellulose was decomposed first, followed by cellulose and lignin $[14,15,18,31,73]$. The volatile compounds and gases, including $\mathrm{CO}_{2}, \mathrm{CO}, \mathrm{H}_{2} \mathrm{O}$ and volatile hydrocarbons, were decomposed, while the amorphous carbon was formed $[43,57,77]$. The pyrolysis temperature of greater than $400{ }^{\circ} \mathrm{C}$ led to an increased amount of volatile compounds, which helped boost the content of aromatic structures $[23,40]$.

The result showed that CSB had a higher carbon content than the biomass feedstock, which was solely organic carbon. This result from at pyrolysis temperature of $400-600{ }^{\circ} \mathrm{C}$, chemical bonds of aromatic organic groups in biomass was broken and rearranged, causing biochar composition to become amorphous carbon $[20,33,51,77]$ that formed aromatic ring. The principal constituent of biochar was highly stable carbon $[47,51,56,68]$. The CSB showed decreased $\mathrm{N}, \mathrm{H}$, and $\mathrm{O}$ contents at pyrolysis temperatures greater than $400{ }^{\circ} \mathrm{C}[28,29,69,78]$. The $\mathrm{N}$ contents of CSB decreased as it was released continuously during the pyrolysis process. A previous study found that the $\mathrm{N}$ contents in biochar decreased by more than half from the nitrogen contained in feedstocks $[29,30]$.

Atomic ratios of elements, including aromaticity $(\mathrm{H} / \mathrm{C}$ ratio) and polarity $(\mathrm{O} / \mathrm{C}$ ratio), were essential to evaluate the stability of biochar in the soil $[53,63,78]$. Therefore, CSB with the low value of the $\mathrm{H} / \mathrm{C}$ ratio indicated that CSB had high aromaticity with increased resistance in the soil. CSB persisted in the soil for a long time, with $\mathrm{H} / \mathrm{C}$ value of less than 0.7, according to the European Biochar Certificate (EBC) [67]. Considering the molar $\mathrm{O} / \mathrm{C}$ ratio, according to Spokas [78], it could be concluded that CSB can persist in soil for 100-1000 years.

Anionic functional groups such as $-\mathrm{OH},-\mathrm{COOH}$, and $-\mathrm{C}(=\mathrm{O}) \mathrm{H},-\mathrm{CHO}$ formed and occurred on the surface area $[30,43,62]$. By contrast, the acidic functional groups were removed $[39,43,62,63]$. Cellulose and lignin degradation and formation of the channel structure increased the surface area and pore volume of biochar $[12,16,30,48]$, while pyrolysis temperature influenced the molecular structure and pores size distribution $[30,34,43,48]$. Destruction of bonding connection between the internal structure of the biochar resulted in increased pore volumes and decreased porosity diameter. The rearrangement of the carbon atoms in biochar generated a highly porous structure [57]. These reasons showed that the results of CSB had more significant surface area and total pore volume than feedstocks, while average pore diameter was less than feedstocks. As mentioned above, the structure of biochar thereby affected the adsorption characteristics $[10,25,47,56,63]$, including nutrient absorption in the soil. 
The analysis results following the transformation of the cassava stem into biochar revealed that CSB increased alkalinity and CEC was decreased. This result, caused by pyrolysis biomass feedstock at a temperature greater than $400{ }^{\circ} \mathrm{C}$, affected the increase in carbonized fractions [8]. At the same time, the removal of surface functional groups and the formation of aromatic carbon caused CEC to decrease $[30,43,62,63]$. Increased $\mathrm{pH}$ of biochar resulted from inorganic, carbonate, and organic substances that had negative ions in the biochar structure caused by the pyrolysis process $[24,37,38,79]$. The pyrolysis temperature and feedstock types also determined the number of nutrients in the biochar as macronutrients and micronutrients $[9,20,37,71]$. Biochar produced from different feedstocks had different nutrient contents $[16,20,37,38]$. Biochar produced from manure had the highest nutrient contents, followed by biochar produced from agricultural wastes and biochar produced from wood residues [11,37]. In this study, CSB produced from agricultural wastes showed increased macronutrient contents.

\subsection{Enhanced Maize Yield with Incorporated Soil with Biochar}

The results showed that cultivation applying CSB into the soil increased maize yield more than fertilizer (TM) and non-soil amendment (TC). Maize yield and nutritional contents in seeds increased more when mixing the soil with fertilizer and CSB at $2.5 \mathrm{~kg} / \mathrm{m}^{2}$ (TMB2.5) and $3.0 \mathrm{~kg} / \mathrm{m}^{2}$ (TMB3.0). Maize gave optimal productivity when cultivated using fertilizer mixed with CSB at $3.0 \mathrm{~kg} / \mathrm{m}^{2}$. Maize yield increased when soil properties were improved by amendments such as fertilizer and biochar. The soil had good conditions suitable for plant growth, with higher productivity than untreated soil.

Maize was grown using fertilizer alone (TM) as the regular pattern had lower productivity of fresh seed weight, dry seed weight and seed biomass than cultivation using CSB mixed into the soil. CSB application provided the appropriate condition and nutrients for plant growth. The addition of CSB improved soil properties, and the plants grew better than applying fertilizing because of the stability of the structure and its properties.

The high aromatic compound structure of biochar was challenging to decompose $[23,31,43,56,63]$, while the high oxidation reaction from the carboxyl functions caused net negative ions $[26,27,69]$. Biochar had a high surface area, promoting carboxylic (COO-) oxidation reaction with soil solutions [43,61]. This study resulted in negative charges on the surface area exchanged with positive charges $\left(\mathrm{H}^{+}\right)$in the soil solution $[23,39,42,79]$. CSB had a pore size of $24.358 \AA$, classified as mesoporous and was influenced by the Van der Waals forces [6]. As a result, CSB absorbed and stored water and plant nutrients in the soil solution in its pores. The adsorption mechanism depended on the $C E C$, the surface area size and the functional groups on the surface area of biochar $[10,18,32,46,57]$. Therefore, the CSB with a high surface area enhanced ion exchange with nutrients at the large surface.

Moreover, many anionic functional groups such as carboxylic at the surface area of biochar $[30,43,57,62]$ made the soil suitable for the positive exchange of nutrients dissolved in the soil solution $[10,24,68,80]$. As a result, mixing CSB into the soil could increase the CEC of soil. However, mixing organic fertilizer into the soil also improved the CEC of soil indirectly from the fertilizer, which was decomposed by soil microbes as humus, which had a high CEC value. For such reasons, the results showed that biochar mixing with fertilizer into the soil could increase the CEC of soil more significantly than using fertilizer and biochar alone. An increase in soil CEC and increasing CSB, which had high stability carbon, thus caused the biochar to persist in the soil longer than fertilizer. High porosity and $\mathrm{C} / \mathrm{N}$ ratio were critical parameters that indicated the excellent retaining soil nutrients and reduced fertilizer runoff, with high soil nutrient content after maize cultivation. These findings concurred with many previous studies that reported increased CEC in soils with biochar application that improved nutrient stability and retention $[50,58,60]$. The nutrient contents in CSB might not have been high, but they were in a form that reflected the actual availability of these nutrients to plants. 
After cultivation, the soil was slightly alkaline in the experimental plot, as suitable for maize growth. The results showed that soil $\mathrm{pH}$ increased according to the amount of biochar mixed in the soil. Due to biochar undergoing pyrolysis, CSB contained alkaline components such as organic anions and inorganic carbonates [21,60]. The soil $\mathrm{pH}$ was also related to the CEC value that impacted buffering capacity [38,67]. Moreover, results indicated that applying only CSB in sufficient quantities $\left(2.5\right.$ and $3.0 \mathrm{~kg} / \mathrm{km}^{2}$ ) increased soil $\mathrm{pH}$ more than fertilizer alone. The soil buffering capacity required sufficient biochar [38], while soil $\mathrm{pH}$ directly and indirectly affected plant growth [21,79]. The soil had increased fertility due to increased $\mathrm{pH}$, nutrients in the soil, nutrient solubility, and absorption of elements in plant roots $[10,50,55,73]$, promoting plant growth.

Biochar improved the physical and chemical properties of the soil to have a suitable environment for plant growth, as discussed above. In addition, CSB contained the primary nutrients, including $\mathrm{N}, \mathrm{P}$, and $\mathrm{K}$, in which $\mathrm{P}$ and $\mathrm{K}$ in biochar presented a soluble form that the plant could be used. Meanwhile, incorporating CSB with fertilizer into the soil promoted the growth of maize better than using CSB and the fertilizer alone. Because the plant could uptake nutrients from both biochar and fertilizers, the nutrients released from the fertilizer, especially $\mathrm{N}$ and $\mathrm{P}$, reacted with the surface of biochar and were stored in the biochar pore $[19,24,26,35]$. Therefore, the nutrients remain in the soil, and plant roots can uptake nutrients for the long term $[10,55,58,68]$.

Many previous studies indicated that biochar contributed to a suitable environment for plant roots growth, promoted nutrient absorption, and transferred the to the stem [48,51]. The soil showed increased OM and nutrients when entering organic compounds as a fertilizer and biochar. An increase in soil OM showed that reasonably large amounts of carbon and exchangeable cations were introduced by biochar application $[34,46,54]$. The soil microorganisms decomposed the $\mathrm{OM}$ in the soil at a rate depending on organic matter types. Fertilizer containing nutrients was mixed with CSB, and the nutrients from the fertilizer were then adsorbed and retained in the pore of CSB. Biochar also helped various nutrients in fertilizers to be more effective by impacting the biological process of the work of soil microbial that caused nitrogen transformation [41,56].

As mentioned above regarding the performance of biochar and biochar's mechanism, the results stated that adding biochar into unfertile soil enhanced nutrient availability and increased yield and plant biomass. These findings were consistent with previous field research $[22,35,39,42,71]$. The results of improved soil and increased yields had good results in different regional environments such as soil in the central region of China [74], midwestern soil [60], Caribbean lowlands [52], and tropical soil in Thailand [11,48,85]. Moreover, biochar application as a soil amendment also produced long-term results in cultivating more than one planting cycle [44,85]. Biochar also helped store various nutrients in ions that could be released to the plant and used for long-term growth $[31,34,54]$. Biochar also reduced the leaching and loss of nutrients in tropical soil, allowing the gradual release of nutrients to plants to use efficiently $[58,60]$. Therefore, applying CSB mixed with fertilizer into the soil supported maize growth and produced high yields. In addition, the nutrient contents and fertility in the soil remained after cultivation.

Although, the maize yields and productivity obtained from the experimental treatment with biochar treated and biochar mixed with fertilizer did not have statistically significant differences when comparing all treatments. After planting, the analysis results of soil properties pointed out that biochar could improve soil properties, especially in the level of macronutrients in the soil, which was a statistically significant increase.

This study was the cultivation of maize for the first plantation crop in an area with low fertility. Due to biochar as an organic soil amendment to increase plant productivity, it might take time in the unfertile soil to allow biochar to improve the soil properties. The effect of biochar on soil depended on soil texture, soil fertility, types of feedstocks, and pyrolysis temperature $[49,57,68]$. The type of biochar and the pyrolysis temperature affected the soil improvement as the above discussion. Previous research found that the age of biochar in the soil was an important factor in its work $[48,68]$. The mechanism of 
the biochar to improve the soil and support plants grown took a starting period of about 1-6 months, which was when the mechanism of biochar in the soil occurred [10]. The mechanisms included the reaction on the biochar surface area to improve the soil $\mathrm{pH}$, ion exchange of nutrients in the soil solution and improving the environment in the soil to suit the activity of soil microbial that was beneficial to plant growth.

These findings were consistent with the previous study, stating that biochar in plant cultivation would see the results clearly in the second-third planting cycle $[22,68,74,85]$. For instance, Wijitkosum [48] indicated that rice husk biochar improved and revitalised saline-sodic soil to present precise results over the past six months, which rice yields were likely to be better, but it could not state results significantly. It took more than two cultivation cycles for biochar to affect rice productivity. Similarly, Major et al. [24] stated that biochar showed the efficiency of increasing the maize yields and nutrients significantly in the third year. In contrast, some research stated that biochar could increase crop yield significantly in the first planting cycle [11]. These results highlight the importance of biochar's operating mechanisms and different effectiveness, in which the soil resource condition was one of the critical factors.

\section{Conclusions}

Biochar is produced from cassava stems as agricultural waste abandoned after cultivation in field crops. Biochar could be produced within the cultivated area, reducing fuel consumption and transportation costs for handling raw materials and reducing soil destruction from burning agricultural wastes. Cassava stems biochar could be produced by slow pyrolysis using a patented furnace designed for appropriate local use. The study applied the CSB to increase maize productivity and improve the properties of unfertile soil. The results indicated that using CSB as a soil amendment increased maize productivity and yield, dry seed weight, fresh seed weight, biomass in seeds and number of ears compared with planting in untreated soil. Higher productivity and yield were obtained than using fertilizer as the typical planting pattern of farmers. Maize yield and nutritional contents in seeds increased when mixing fertilizers with CSB at 2.5 and $3.0 \mathrm{~kg} / \mathrm{m}^{2}$. Maize gave optimal productivity using fertilizer mixed with biochar at $3.0 \mathrm{~kg} / \mathrm{m}^{2}$.

Moreover, mixing the appropriate rate of CSB into the soil and mixing CSB with fertilizers significantly increased the number of ears of maize. The results showed that the physicochemical properties of the soil improved, including $\mathrm{pH}, \mathrm{CEC}, \mathrm{OM}$ and nutrients to suit maize cultivation. Treated soil had a significant amount of organic matter and nutrients when mixing CSB at $3.0 \mathrm{~kg} / \mathrm{m}^{2}$ and fertilizer mixed with CSB at the same rate. Fresh seed weight, dry seed weight and biomass of seeds in each experimental plot were not significantly different. However, soil analysis results after cultivation pointed out that CSB improved soil properties, primarily by increasing soil fertility and maintaining nutrient contents in the soil after cultivation. The results suggested that using CSB for maize cultivation could assist farmers in increasing productivity, improving soil properties, and promoting agricultural waste management.

Author Contributions: Conceptualization, S.W.; methodology, S.W.; data curation, S.W.; resources, T.S.; formal analysis, S.W.; investigation, S.W.; project administration, S.W. and T.S.; supervision, T.S.; writing—original draft, S.W.; writing—review and editing, S.W. and T.S. All authors have read and agreed to the published version of the manuscript.

Funding: The research was funded by the 2014 In-depth Strategic Research Fund, Ratchadapisek Sompoch Endowment Fund, Chulalongkorn University.

Institutional Review Board Statement: Not applicable.

Informed Consent Statement: Not applicable.

Acknowledgments: Pa-deng Biochar Research Center supported the CTBRSPP retorts and experimental area.

Conflicts of Interest: The authors declare no conflict of interest. 


\section{References}

1. Wijitkosum, S. Reducing Vulnerability to Desertification by Using the Spatial Measures in a Degraded Area in Thailand. Land 2020, 9, 49. [CrossRef]

2. Kopittke, P.M.; Menzies, N.W.; McKenna, B.A.; Lombi, E. Soil and the intensification of agriculture for global food security. Environ. Int. 2019, 132, 105078. [CrossRef] [PubMed]

3. Wijitkosum, S. Factor influencing land degradation sensitivity and desertification in a drought prone watershed in Thailand. ISWCR Int. Soil Water Conserv. Res. 2021, 9, 217-228. [CrossRef]

4. Savci, S. Investigation of Effect of Chemical Fertilizers on Environment. APCBEE Procedia 2012, 1, 287-292. [CrossRef]

5. United Nations. Transforming Our World: The 2030 Agenda for Sustainable Development. Available online: https://sdgs.un. org/sites/default/files/publications/21252030\%20Agenda\%20for\%20Sustainable\%20Development\%20web.pdf (accessed on 15 July 2021).

6. Wijitkosum, S. Biochar derived from agricultural wastes and wood residues for sustainable agricultural and environmental applications. ISWCR Int. Soil Water Conserv. Res. 2021, in press. [CrossRef]

7. Department of Agricultural Extension. Agricultural Extension Information. Available online: http://www.agriinfo.doae.go.th/ year/63plant/rortor/page.pdf (accessed on 20 August 2021).

8. Zhang, J.; Liu, J.; Liu, R. Effects of pyrolysis temperature and heating time on biochar obtained from the pyrolysis of straw and lignosulfonate. Bioresour. Technol. 2015, 176, 288-291. [CrossRef] [PubMed]

9. Bera, T.; Purakayastha, T.J.; Patra, A.K.; Datta, S.C. Comparative analysis of physicochemical, nutrient and spectral properties of agricultural residue biochars as influenced by pyrolysis temperatures. J. Mater. Cycles Waste Manag. 2017, 20, 1115-1127. [CrossRef]

10. Joseph, S.; Cowie, A.L.; Van Zwieten, L.; Bolan, N.; Budai, A.; Buss, W.; Cayuela, M.L.; Graber, E.R.; Ippolito, J.A.; Kuzyakov, Y.; et al. How biochar works, and when it doesn't: A review of mechanisms controlling soil and plant responses to biochar. GCB Bioenergy 2021, 13, 1731-1764. [CrossRef]

11. Sriburi, T.; Wijitkosum, S. Biochar Amendment Experiments in Thailand: Practical Examples. In Biochar a Regional Supply Chain Approach in View of Climate Change Mitigation; Bruckman, V.J., Varol, E.A., Uzun, B.B., Liu, J., Eds.; Cambridge University Press: Cambridge, UK, 2016; pp. 351-367.

12. Yu, H.; Zhang, Z.; Li, Z.; Chen, D. Characteristic of tar formation during cellulose, hemicellulose and lignin gasification. Fuel 2014, 118, 25-256. [CrossRef]

13. Bong, C.P.; Lim, L.Y.; Lee, C.T.; Ong, P.Y.; Klemeš, J.J.; Li, C.; Gao, Y. Lignocellulosic Biomass and Food Waste for Biochar Production and Application: A Review. Chem. Eng. Transac. 2020, 81, 427-432. [CrossRef]

14. Rangabhashiyam, S.; Balasubramanian, P. The potential of lignocellulosic biomass precursors for biochar production: Performance, mechanism and wastewater application-A review. Ind. Crop. Prod. 2019, 128, 405-423. [CrossRef]

15. Dhyani, V.; Bhaskar, T. A comprehensive review on the pyrolysis of lignocellulosic biomass. Renew. Energy 2018, 129, 695-716. [CrossRef]

16. Tomczyk, A.; Sokołowska, Z.; Boguta, P. Biochar physicochemical properties: Pyrolysis temperature and feedstock kind effects. Rev. Environ. Sci. Bio/Technol. 2020, 19, 191-215. [CrossRef]

17. Sharma, P.; Marinov, I.; Cabre, A.; Kostadinov, T.; Singh, A. Increasing biomass in the warm oceans: Unexpected new insights from SeaWiFS. Geophys. Res. Lett. 2019, 46, 3900-3910. [CrossRef]

18. Wang, S.; Gao, B.; Zimmerman, A.R.; Li, Y.; Ma, L.; Harris, W.G.; Migliaccio, K.W. Physicochemical and sorptive properties of biochars derived from woody and herbaceous biomass. Chemosphere 2015, 134, 257-262. [CrossRef]

19. Ronsse, F.; van Hecke, S.; Dickinson, D.; Prins, W. Production and characterization of slow pyrolysis biochar: Influence of feedstock type and pyrolysis conditions. Glob. Chang. Biol. Bioenergy 2012, 5, 104-115. [CrossRef]

20. Jindo, K.; Mizumoto, H.; Sawada, Y.; Sanchez-Monedero, M.A.; Sonoki, T. Physical and chemical characterization of biochars derived from different agricultural residues. Biogeosciences 2014, 11, 6613-6621. [CrossRef]

21. Yuan, J.; Xu, R.; Zhang, H. The forms of alkalis in the biochar produced from crop residues at different temperatures. Bioresour. Technol. 2011, 102, 3488-3497. [CrossRef]

22. Huang, M.; Fan, L.; Jiang, L.G.; Yang, S.Y.; Zou, Y.B.; Norman, U. Continuous applications of biochar to rice: Effects on grain yield and yield attributes. J. Integr. Agric. 2019, 18, 563-570. [CrossRef]

23. Novak, J.M.; Lima, I.; Xing, B.; Gaskin, J.W.; Steiner, C.; Das, K.C.; Ahmedna, M.; Rehrah, D.; Watts, D.W.; Busscher, W.J. Characterization of designer biochar produced at different temperatures and their effects on a loamy sand. Ann. Environ. Sci. 2009, 3, 195-206.

24. Major, J.; Rondon, M.; Molina, D.; Riha, S.J.; Lehmann, J. Maize yield and nutrition during 4 years after biochar application to a Colombian savanna oxisol. Plant Soil 2010, 333, 117-128. [CrossRef]

25. Ahmad, M.; Lee, S.S.; Dou, X.; Mohan, D.; Sung, J.K.; Yang, J.E.; Ok, Y.S. Effects of pyrolysis temperature on soybean stover- and peanut shell-derived biochar properties and TCE adsorption in water. Bioresour. Technol. 2012, 118, 536-544. [CrossRef]

26. Chintala, R.; Mollinedo, J.; Schumacher, T.E.; Malo, D.D.; Julson, J.L. Effect of biochar on chemical properties of acidic soil. Arch. Agron. Soil Sci. 2014, 60, 393-404. [CrossRef]

27. Brewer, C.E.; Brown, R.C. Biochar. In Comprehensive Renewable Energy; Sayigh, A., Ed.; Elsevier: Oxford, UK, 2012 ; pp. 357-384. 
28. Cai, Y.J.; Ok, Y.S.; Lehmann, J.; Chang, S.X. Recommendations for stronger biochar research in soil biology and fertility. Biol. Fertil. Soils 2021, 57, 333-336. [CrossRef]

29. Lang, T.; Jensen, A.D.; Jensen, P.A. Retention of organic elements during solid fuel pyrolysis with emphasis on the peculiar behavior of nitrogen. Energy Fuel 2005, 19, 1631-1643. [CrossRef]

30. Bagreev, A.; Bandosz, T.; Locke, D. Pore structure and surface chemistry of adsorbents obtained by pyrolysis of sewage-derived fertilizer. Carbon 2001, 39, 1971-1979. [CrossRef]

31. Wijitkosum, S.; Jiwnok, P. Elemental Composition of Biochar Obtained from Agricultural Waste for Soil Amendment and Carbon Sequestration. Appl. Sci. 2019, 9, 3980. [CrossRef]

32. Weber, K.; Quicker, P. Properties of biochar. Fuel 2018, 217, 240-261. [CrossRef]

33. Doumer, M.E.; Arízaga, G.G.C.; da Silva, D.A.; Yamamoto, C.I.; Novotny, E.H.; Santos, J.M.; dos Santos, L.O.; Wisniewski, A., Jr.; de Andrade, J.B.; Mangrich, A.S. Slow pyrolysis of different Brazilian waste biomasses as sources of soil conditioners and energy, and for environmental protection. J. Anal. Appl. Pyrolysis 2015, 113, 434-443. [CrossRef]

34. Gaskin, J.; Steiner, C.; Harris, K.; Das, K.; Bibens, B. Effect of low temperature pyrolysis conditions on biochar for agricultural use. Trans. ASABE 2008, 51, 2061-2069. [CrossRef]

35. Ding, Y.; Liu, Y.G.; Liu, S.B.; Li, Z.W.; Tan, X.F.; Huang, X.X. Biochar to improve soil fertility: A review. Agron. Sustain. Dev. 2016, 36, 36. [CrossRef]

36. Ding, Y.; Liu, Y.; Liu, S.; Huang, X.; Li, Z.; Tan, X.; Zeng, G.; Zhou, L. Potential Benefits of Biochar in Agricultural Soils: A Review. Pedosphere 2017, 27, 645-661. [CrossRef]

37. Tsai, W.T.; Liu, S.C.; Chen, H.R.; Chang, Y.M.; Tsai, Y.L. Textural and chemical properties of swine-manure-derived biochar pertinent to its potential use as a soil amendment. Chemosphere 2012, 89, 198-203. [CrossRef]

38. Yuan, J.H.; Xu, R.K. The amelioration effects of low temperature biochar generated from nine crop residues on an acidic Ultisol. Soil Use Manag. 2010, 27, 110-115. [CrossRef]

39. Murtaza, G.; Ahmed, Z.; Usman, M.; Tariq, W.; Ullah, Z.; Shareef, M.; Iqbal, H.; Waqas, M.; Tariq, A.; Wu, Y.; et al. Biochar induced modifications in soil properties and its impacts on crop growth and production. J. Plant Nutr. 2021, 44, 1677-1691. [CrossRef]

40. Sun, X.; Zhong, T.; Zhang, L.; Zhang, K.; Wu, W. Reducing ammonia volatilization from paddy field with rice straw derived biochar. Sci. Total Environ. 2019, 660, 512-518. [CrossRef]

41. Sarfraz, R.; Hussain, A.; Sabir, A.; Fekih, I.B.; Ditta, A.; Xing, S. Role of biochar and plant growth promoting rhizobacteria to enhance soil carbon sequestration-A review. Environ. Monit. Assess. 2019, 191, 251. [CrossRef]

42. Schmidt, M.W.I.; Noack, A.G. Black carbon in soils and sediments: Analysis, distribution, implications, and current challenges. Glob. Biogeochem. Cycles 2000, 14, 777-793. [CrossRef]

43. Janu, R.; Mrlik, V.; Ribitsch, D.; Hofman, J.; Sedláček, P.; Bielská, L.; Soja, G. Biochar surface functional groups as affected by biomass feedstock, biochar composition and pyrolysis temperature. Carbon Resour. Convers. 2021, 4, 36-46. [CrossRef]

44. Nelissen, V.; Ruysschaert, G.; Manka'Abusi, D.; D’Hose, T.; De Beuf, K.; Al-Barri, B.; Cornelis, W.; Boeckx, P. Impact of a woody biochar on properties of a sandy loam soil and spring barley during a two-year field experiment. Eur. J. Agron. 2015, 62, 65-78. [CrossRef]

45. Guo, M.; Wwiping, S.; Jing, T. Biochar-Facilitated Soil Remediation: Mechanisms and Efficacy Variations. Front. Environ. Sci. 2020, 8, 183. [CrossRef]

46. Li, H.; Dong, X.; da Silva, E.B.; de Oliveira, L.M.; Chen, Y.; Ma, L.Q. Mechanisms of metal sorption by biochars: Biochar characteristics and modifications. Chemosphere 2017, 178, 466-478. [CrossRef]

47. Chen, T.; Zhang, Y.; Wang, H.; Lu, W.; Zhou, Z.; Zhang, Y.; Ren, L. Influence of pyrolysis temperature on characteristics and heavy metal adsorptive performance of biochar derived from municipal sewage sludge. Bioresour. Technol. 2014, 164, 47-54. [CrossRef]

48. Wijitkosum, S. Applying Rice Husk Biochar to Revitalise Saline Sodic Soil in Khorat Plateau Area-A Case Study for Food Security Purposes. In Biochar Applications in Agriculture and Environment Management; Shankar, S.J., Chhatarpal, S., Eds.; Springer Nature: Cham, Switzerland, 2020; pp. 1-31.

49. Stewart, C.E.; Zheng, J.; Botte, J.; Cotrufo, F. Co-Generated fast pyrolysis biochar mitigates greenhouse gas emission and increases carbon sequestration in temperature soil. Glob. Chang. Biol. Bioenergy 2013, 5, 153-164. [CrossRef]

50. Spokas, K.A.; Cantrell, K.B.; Novak, J.M.; Archer, D.W.; Ippolito, J.A.; Collins, H.P.; Boateng, A.A.; Lima, I.M.; Lamb, M.C.; McAloon, A.J.; et al. Biochar: A synthesis of its agronomic impact beyond carbon sequestration. J. Environ. Qual. 2012, 41, 973-989. [CrossRef]

51. Sohi, S.P.; Lopez-Capel, E.; Krull, E.; Bol, R. Biochar, climate change and soil: A review to guide future research. CSIRO Land Water Sci. Rep. 2009, 5, 17-31.

52. Redondo-Brenes, A.; Montagnini, F. Growth, productivity, aboveground biomass, and carbon sequestration of pure and mixed native tree plantations in the Caribbean lowlands of Costa Rica. For. Ecol. Manag. 2006, 232, 168-178. [CrossRef]

53. Tan, Z.; Lin, C.S.K.; Ji, X.; Rainey, T.J. Returning biochar to fields: A review. Appl. Soil Ecol. 2017, 116, 1-11. [CrossRef]

54. Al-Wabel, M.I.; Hussain, Q.; Usman, A.R.A.; Ahmad, M.; Abdulijabbar, A.; Sallam, A.S.; Ok, Y.S. Impact of biochar properties on soil conditions and agricultural sustainability: A review. Land Degrad. Dev. 2018, 29, 2124-2161. [CrossRef]

55. Lehmann, J.; Joseph, S. (Eds.) Biochar for environmental management: An introduction. In Biochar for Environmental Management: Science, Technology and Implementation; Taylor and Francis: London, UK, 2015; pp. 1-13. 
56. Gul, S.; Whalen, J.K.; Thomas, B.W.; Sachdeva, V.; Deng, H. Physico-chemical properties and microbial responses in biocharAmended soil mechanism and future directions. Agric. Ecosyst. Environ. 2015, 206, 46-59. [CrossRef]

57. Amonette, J.; Joseph, S. Characteristics of Biochar: Micro Chemical Properties. In Biochar for Environmental Management: Science and Technology; Lehmann, J., Joseph, S., Eds.; Earthscan: London, UK, 2009; pp. 33-52.

58. Bohara, H.; Dodla, S.; Wang, J.J.; Darapuneni, M.; Acharya, B.S.; Magdi, S.; Pavuluri, K. Influence of poultry litter and biochar on soil water dynamics and nutrient leaching from a very fine sandy loam soil. Soil Tillage Res. 2019, 189, 44-51. [CrossRef]

59. Lehmann, J.; Rillig, M.C.; Thies, J.; Masiello, C.A.; Hockaday, W.C.; Crowley, D. Biochar effects on soil biota-A review. Soil Biol. Biochem. 2011, 43, 1812-1836. [CrossRef]

60. Laird, D.A.; Fleming, P.; Wang, B.Q.; Horton, R.; Karlen, D. Biochar impact on nutrient leaching from a Midwestern agricultural soil. Geoderma 2010, 158, 436-442. [CrossRef]

61. Cheng, C.-H.; Lehmann, J.; Thies, J.E.; Burton, S.D.; Engelhard, M.H. Oxidation of black carbon by biotic and abiotic processes. Org. Geochem. 2006, 37, 1477-1488. [CrossRef]

62. Wang, J.; Wang, S. Preparation, modification and environmental application of biocar: A review. J. Clean. Prod. 2019, 227, 1002-1022. [CrossRef]

63. Han, L.; Qian, L.; Yan, J.; Chen, M. Effects of the biochar aromaticity and molecular structures of the chlorinated organic compounds on the adsorption characteristics. Environ. Sci. Pollut. Res. 2017, 24, 5554-5565. [CrossRef]

64. Wijitkosum, S. Impacts of land use changes on soil erosion in Pa Deng sub-district, adjacent area of Kaeng Krachan National Park, Thailand. Soil Water Res. 2012, 7, 10-17. [CrossRef]

65. Department of Agricultural Extension. Handbook for Maize Production; Department of Agricultural Extension: Bangkok, Thailand, 2008. (In Thai)

66. Department of Agriculture. DOA Notice on the Standard of Organic Fertilisers, B.E. 2548 (In Thai). Available online: http: / / www.ratchakitcha.soc.go.th/DATA/PDF/2548/00172707.PDF (accessed on 15 July 2020).

67. International Biochar Initiative. Standardized Product Definition and Product Testing Guidelines for Biochar that Is Used in Soil. Available online: https:/ /www.biochar-international.org/wp-content/uploads/2018/04/IBI_Biochar_Standards_V2.1_Final.pdf (accessed on 15 July 2020).

68. Haider, G.; Joseph, S.; Steffens, D.; Müller, C.; Taherymoosavi, S.; Mitchell, D.; Kammann, C.I. Mineral nitrogen captured in field-aged biochar is plant-available. Sci. Rep. 2020, 10, 13816. [CrossRef]

69. Hammes, K.; Smernik, R.J.; Skjemstad, J.O.; Schmidt, M.W.I. Characterization and evaluation of reference materials for black carbon analysis using elemental composition, colour, BET surface area and ${ }^{13} \mathrm{C}$ NMR spectroscopy. Appl. Geochem. 2008, 23, 2113-2122. [CrossRef]

70. Wang, T.; Stewart, C.E.; Suna, C.; Wang, Y.; Zheng, J. Effects of biochar addition on evaporation in the five typical Loess Plateau Soils. Catena 2018, 162, 29-39. [CrossRef]

71. Liu, W.J.; Jiang, H.; Yu, H.Q. Development of Biochar-Based Functional Materials: Toward a Sustainable Platform Carbon Material. Chem. Rev. 2015, 115, 12251-12285. [CrossRef] [PubMed]

72. Lee, Y.; Park, J.; Ryu, C.; Gang, K.S.; Yang, W.; Park, Y.; Jung, J.; Hyun, S. Comparison of biochar properties from biomass residues produced by slow pyrolysis at $500{ }^{\circ} \mathrm{C}$. Bioresour. Technol. 2013, 148, 196-201. [CrossRef] [PubMed]

73. Zhang, M.; Gao, B.; Varnoosfaderani, S.; Hebard, A.; Yao, Y.; Inyang, M. Preparation and characterization of a novel magnetic biochar for arsenic removal. Bioresour. Technol. 2013, 130, 457-462. [CrossRef]

74. Liu, X.; Ye, Y.; Liu, Y.; Zhang, A.; Zhang, X.; Li, L.; Pan, G.; Kibue, G.W.; Zheng, J.; Zheng, J. Sustainable biochar effects for low carbon crop production: A 5-crop season field experiment on a low fertility soil from Central China. Agric. Syst. 2014, 129, 22-29. [CrossRef]

75. Kambo, H.S.; Dutta, A. A comparative review of biochar and hydrochar in terms of production physico-Chemical properties and applications. Renew. Sustain. Energy. Rev. 2015, 45, 359-378. [CrossRef]

76. Gai, X.; Wang, H.; Liu, J.; Zhai, L.; Liu, S.; Ren, T.; Liu, H. Effects of Feedstock and Pyrolysis Temperature on Biochar Adsorption of Ammonium and Nitrate. PLoS ONE 2014, 9, e113888. [CrossRef]

77. Yu, J.T.; Dehkhoda, A.M.; Ellis, N. Development of biochar-based catalyst for transesterification of canola oil. Energy Fuels 2011, 25, 337-344. [CrossRef]

78. Spokas, K.A. Review of the stability of biochar in soils: Predictability of O:C molar ratios. Carbon Manag. 2010, 1, 289-303. [CrossRef]

79. Gezahegn, S.; Sain, M.; Thomas, S.C. Variation in Feedstock Wood Chemistry Strongly Influences Biochar Liming Potential. Soil Syst. 2019, 3, 26. [CrossRef]

80. Domingues, R.R.; Sánchez-Monedero, M.A.; Spokas, K.A.; Melo, L.C.A.; Trugilho, P.F.; Valenciano, M.N.; Silva, C.A. Enhancing Cation Exchange Capacity of Weathered Soils Using Biochar: Feedstock, Pyrolysis Conditions and Addition Rate. Agronomy 2020, 10, 824. [CrossRef]

81. Bray, R.H.; Kurtz, L.T. Determination of Total, Organic, and Available Forms of Phosphorus in Soils. Soil Sci. 1945, 59, 39-45. [CrossRef]

82. Jackson, M.L. Soil Chemical Analysis; Prentice Hall of India Pvt. Ltd.: New Delhi, India, 1973; 498p.

83. Walkley, A.J.; Black, I.A. Estimation of soil organic carbon by the chromic acid titration method. Soil Sci. 1934, 37, 29-38. [CrossRef] 
84. Gavlak, R.; Horneck, D.; Miller, R.O. Soil, Plant and Water Reference Methods for the Western Region. Available online: www.naptprogram.org/files/napt/western-states-methodmanual-2005.pdf (accessed on 15 July 2020).

85. Wijitkosum, S.; Sriburi, T. Increasing the Amount of Biomass in Field Crops for Carbon Sequestration and Plant Biomass Enhancement Using Biochar. In Biochar-An Imperative Amendment for Soil and the Environment; IntechOpen: London, UK, 2018. Available online: http:/ / www.intechopen.com/online-first/increasing-theamount-of-biomass-in-field-crops-for-carbonsequestration-and-plant-biomass-enhanceme (accessed on 10 August 2021).

86. AOAC. Official Methods of Analysis, 15th ed.; Wilson Boulevard: Arlington, VA, USA, 2000; 1298p. 